\title{
Effects of barium substitution on the sintering behavior, dielectric properties of $\mathrm{Ca}_{2} \mathrm{Nb}_{2} \mathrm{O}_{7}$ ferroelectric ceramics
}

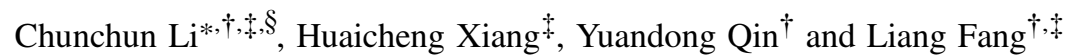 \\ *College of Information Science and Engineering \\ Guilin University of Technology, Guilin 541004, P. R. China \\ ${ }^{\dagger}$ Guangxi New Future Information Industry Co. Ltd \\ Beihai 536005, P. R. China \\ ${ }^{*}$ State Key Laboratory Breeding Base of Nonferrous Metals and Specific Materials Processing \\ Guangxi Universities Key Laboratory of Nonferrous Metal Oxide \\ Electronic Functional Materials and Devices \\ College of Material Science and Engineering \\ Guilin University of Technology, Guilin 541004, P. R. China \\ \$lichunchun2003@126.com
}

Received 16 March 2017; Revised 10 April 2017; Accepted 10 April 2017; Published 27 April 2017

\begin{abstract}
Barium-doped $\mathrm{Ca}_{2} \mathrm{Nb}_{2} \mathrm{O}_{7}$ ceramics were prepared in the form of $\mathrm{Ca}_{2-x} \mathrm{Ba}_{x} \mathrm{Nb}_{2} \mathrm{O}_{7}(0 \leq x \leq 0.6)$ by solid-state reaction. The solubility limit of barium in $\mathrm{Ca}_{2} \mathrm{Nb}_{2} \mathrm{O}_{7}$ was found to be $x=0.4$ based on X-ray diffraction and Raman spectroscopy analysis. When $x \leq 0.4, \mathrm{Ca}_{2-x} \mathrm{Ba}_{x} \mathrm{Nb}_{2} \mathrm{O}_{7}$ solid solutions with a monoclinic perovskites-like layered structure (PLS) were formed, whereas beyond $x=0.4$, a secondary phase $\mathrm{CaNb}_{2} \mathrm{O}_{6}$ was detected. The dielectric properties obviously depended on the barium substitution. With increasing barium amount, the dielectric constant increased from 33.5 for pure $\mathrm{Ca}_{2} \mathrm{Nb}_{2} \mathrm{O}_{7}$ to 38.6 for $x=0.4(f=1 \mathrm{MHz})$. The Curie temperature $\left(T_{c}\right)$ of the $x=0.1$ sample was $1280 \pm 5^{\circ} \mathrm{C}$. The phase transition was confirmed to be the second order.
\end{abstract}

Keywords: Dielectric properties; perovskites-like layered structure; barium substitution.

\section{Introduction}

In recent years, the perovskite-like layer structured (PLS) ferroelectrics with a formula of $\mathrm{A}_{n} \mathrm{~B}_{n} \mathrm{O}_{3 n+2}(n=2 \sim 7)$ have received considerable attention in view of their wide ranging properties such as dielectric, ferroelectric, piezoelectric, magnetic, electro-optic, microwave dielectric properties and superconducting properties. ${ }^{1-10}$ The diverse properties of $\mathrm{A}_{n} \mathrm{~B}_{n} \mathrm{O}_{3 n+2}$ are related to their unique structure composed of corner-shared $\mathrm{BO}_{6}$ octahedra with $\mathrm{A}$ cations within the perovskite-like layers, where $n$ is the number of octahedral layers in the perovskite slab. ${ }^{1,2,5}$ In the PLS structure, A sites can accommodate large cations, e.g., alkali metals, alkalineearth metals, and rare earths metals, and B sites (A and B) are available for a wide variety of small cations with high ionic polarizability, such as $\mathrm{Ti}, \mathrm{Nb}, \mathrm{Ta}, \mathrm{W}$, etc.

In the previous reports, the formation and physical properties of the PLS-ed $\mathrm{A}_{n} \mathrm{~B}_{n} \mathrm{O}_{3 n+2}$ compounds with $n=2-6$ have been especially emphasized. ${ }^{1-4,7-10}$ Particularly, much attention has been focused on the $n=4$ series $\left(\mathrm{A}_{2} \mathrm{~B}_{2} \mathrm{O}_{7}\right)$ for their potential use in high-temperature piezoelectric applications because of their super-high Curie points, such as $\mathrm{La}_{2} \mathrm{Ti}_{2} \mathrm{O}_{7}\left(T_{c} \sim 1482^{\circ} \mathrm{C}\right),{ }^{1,11} \mathrm{Nd}_{2} \mathrm{Ti}_{2} \mathrm{O}_{7}\left(T_{c} \sim 1482^{\circ} \mathrm{C}\right),{ }^{1,12}$ $\mathrm{Sr}_{2} \mathrm{Nb}_{2} \mathrm{O}_{7}\left(T_{c} \sim 1482^{\circ} \mathrm{C}\right),{ }^{2,13}$ etc. In addition, efforts have been made to improve the piezoelectric activity of $\mathrm{A}_{2} \mathrm{~B}_{2} \mathrm{O}_{7}$ through compositional modifications and texturing technologies, such as hot-forging, spark plasma sintering (SPS). ${ }^{14-16}$

$\mathrm{Ca}_{2} \mathrm{Nb}_{2} \mathrm{O}_{7}$ is a member of the family of PLS $\mathrm{A}_{n} \mathrm{~B}_{n} \mathrm{O}_{3 n+2^{-}}$ type compounds with $n=4$. Single-crystal $\mathrm{Ca}_{2} \mathrm{Nb}_{2} \mathrm{O}_{7}$ was found to be ferroelectric with extremely high Curie point $\left(T_{c}>1500^{\circ} \mathrm{C}\right)$ in $1970 \mathrm{~s}$. More recently, Ning et al. ${ }^{12}$ have given a reasonable prediction for the Curie point of $\mathrm{Ca}_{2} \mathrm{Nb}_{2} \mathrm{O}_{7}$ to be about $1525^{\circ} \mathrm{C}$, based on the temperature dependence of dielectric spectroscopy. The purpose of the present paper was to study the effects of barium doping on the crystal structure, dielectric properties of $\mathrm{Ca}_{2} \mathrm{Nb}_{2} \mathrm{O}_{7}$.

\section{Experimental}

$\mathrm{Ca}_{2-x} \mathrm{Ba}_{x} \mathrm{Nb}_{2} \mathrm{O}_{7}(0 \leq x \leq 0.6$, abbreviated as $\mathrm{CBN}$, were prepared by high temperature solid state reactions of high purity raw powders $\mathrm{CaCO}_{3}(99.9 \%), \mathrm{BaCO}_{3}(99.9 \%)$, and $\mathrm{Nb}_{2} \mathrm{O}_{5}(99.95 \%)$. The raw powders were weighed and fully mixed in stoichiometric amounts and ball milled for $4 \mathrm{~h}$. The mixtures were dried and calcined at $1250^{\circ} \mathrm{C}$ for $4 \mathrm{~h}$. After calcining, the samples were thoroughly reground and mixed with a $3 \mathrm{wt}$ \% solution of polyvinyl alcohol (PVA) as a

This is an Open Access article published by World Scientific Publishing Company. It is distributed under the terms of the Creative Commons Attribution 4.0 (CC-BY) License. Further distribution of this work is permitted, provided the original work is properly cited. 
binder. The resultant slurries were then dried and pressed into cylindrical compacts of different thickness in the range $1-3 \mathrm{~mm}$ and $11 \mathrm{~mm}$ in diameter under a pressure of $100 \mathrm{MPa}$. The samples were fired at $600^{\circ} \mathrm{C}$ for $2 \mathrm{~h}$ to remove the organic binder and then sintered in the range $1300-1350^{\circ} \mathrm{C}$ for $4 \mathrm{~h}$.

The phase constitutions of the samples were examined using a Rigaku DMAX-RB X-ray diffractometer (XRD) using $\mathrm{CuKa}$ radiation $(\lambda=0.15406 \mathrm{~nm})$ in a $2 \theta$ range from $10^{\circ}$ to $70^{\circ}$. The microstructures were studied using a JSM5610LV scanning electron microscopy (SEM). The densities of the compacts were measured by the Archimedes method. To study the relative density of the samples, the theoretical density was obtained from the crystal structure based on the XRD data.

Prior to dielectric measurements, $\mathrm{Pt}$ pastes were applied to the circular faces, then dried at $900^{\circ} \mathrm{C}$ for $1 \mathrm{~h}$. Temperaturedependent dielectric measurements were made using an HP4294A LCR meter equipped with a thermostat from room temperature $\left(20^{\circ} \mathrm{C}\right)$ to $1400^{\circ} \mathrm{C}$ at $100 \mathrm{kHz}, 500 \mathrm{kHz}$ and $1 \mathrm{MHz}$.

\section{Results and Discussion}

The room temperature XRD patterns performed on the $\mathrm{Ca}_{2-x} \mathrm{Ba}_{x} \mathrm{Nb}_{2} \mathrm{O}_{7}(0 \leq x \leq 0.6)$ powders calcined at $1250{ }^{\circ} \mathrm{C}$ are shown in Fig. 1. Within the limitation of XRD, when $x \leq 0.4$, all the observed diffraction peaks could be indexed based on the standard JCPDF cards (No. 23-0122) for $\mathrm{Ca}_{2} \mathrm{Nb}_{2} \mathrm{O}_{7}$ with a space group $P 2_{1}$, suggesting that barium dissolved into the lattice structure of $\mathrm{Ca}_{2} \mathrm{Nb}_{2} \mathrm{O}_{7}$ to form solid solutions. Nevertheless, the trace amount of a second phase detected as $\mathrm{CaNb}_{2} \mathrm{O}_{6}$ (JCPDF cards No. 39-1392) was observed in CBN ceramics with $x>0.4$. Additionally, it is observed that XRD peaks shifted to lower angles as $x$ increased from 0 to 0.3 , indicating lattice expansion because of

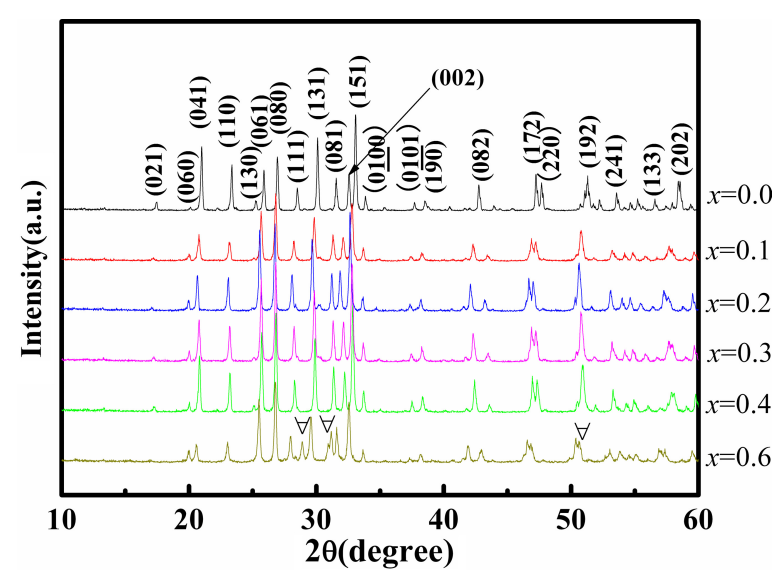

Fig. 1. Room temperature XRD patterns of $\mathrm{Ca}_{2-x} \mathrm{Ba}_{x} \mathrm{Nb}_{2} \mathrm{O}_{7}$ powders calcined at $1250^{\circ} \mathrm{C}$ (Peaks of second phases are marked with triangles). the larger effective ionic radius of $\mathrm{Ba}^{2+}(1.61 \AA)$ than that of $\mathrm{Ca}^{2+}(1.34 \AA)$. The peak shifting terminated with further increase in Ba content. The unit cell parameters $(a, b, c, V)$ refined by the least square method are shown in Fig. 2 as well as the linear fitting based on Vegard's law. As observed, the lattice parameters generally increased as Ba content increased with a nearly linear variation in the range of $0.1-0.3$, which is in well agreement with the lower angle shifting of XRD peaks due to the lattice expansion caused by the larger Ba substitution. Beyond $x=0.3$, a deviation from the Vegard's law was detected. These results indicate that the solid solubility limit of $\mathrm{Ba}$ in $\mathrm{Ca}_{2} \mathrm{Nb}_{2} \mathrm{O}_{7}$ lattice is less than $x=0.4$.

It is well known that Raman spectroscopy is a helpful tool to understand the local vibrational characteristics and is sensitive to the structure evolution of materials. Thus, Raman spectroscopy was employed to further confirm the phase purity and solution limit of $\mathrm{Ca}_{2-x} \mathrm{Ba}_{x} \mathrm{Nb}_{2} \mathrm{O}_{7}$. Figure 3 shows the room temperature Raman spectra of all the $\mathrm{Ca}_{2-x} \mathrm{Ba}_{x} \mathrm{Nb}_{2} \mathrm{O}_{7}$ ceramics in the range $100-1000 \mathrm{~cm}^{-1}$. Similar Raman spectroscopy was observed for the samples with $x=0.1-0.3$. On the other hand, the modes at $120.6 \mathrm{~cm}^{-1}, 280 \mathrm{~cm}^{-1}$ and $779 \mathrm{~cm}^{-1}$ appeared at $x=0.4$ and the intensity increased with $x$ value, along with gradually depressed modes around $132 \mathrm{~cm}^{-1}, 160 \mathrm{~cm}^{-1}$, and $178 \mathrm{~cm}^{-1}$. The modes at $120.6 \mathrm{~cm}^{-1}, 280 \mathrm{~cm}^{-1}$, and $779 \mathrm{~cm}^{-1}$ were attribute to the appearance of $\mathrm{CaNb}_{2} \mathrm{O}_{6}$ phase, which is consistent with the previous report. ${ }^{17} \mathrm{Al}-$ though XRD data showed no diffraction peaks from $\mathrm{CaNb}_{2} \mathrm{O}_{6}$ in the $x=0.4$ sample, the Raman peaks of $\mathrm{CaNb}_{2} \mathrm{O}_{6}$ were detected. The Raman analysis further confirmed that the upper limitation for $\mathrm{Ba}$ substitution in $\mathrm{Ca}_{2} \mathrm{Nb}_{2} \mathrm{O}_{7}$ is less than $x=0.4$. For this reason, only the results from the samples with $x \leq 0.4$ were reported hereafter.

Figure 4 shows the variation of the bulk densities of $\mathrm{Ca}_{2-x} \mathrm{Ba}_{x} \mathrm{Nb}_{2} \mathrm{O}_{7}$ ceramics as a function of sintering temperature. A similar variation tendency with sintering temperature is observed for all samples. The bulk density increased to a maximum value at a critical temperature, and further increase in sintering temperature decreased the density. The optimum sintering temperature was obtained at which the maximum density was achieved and shown in the inset of Fig. 4 as well as the corresponding density maxima. It is found that barium doping significantly lowered the sintering temperature from $1375^{\circ} \mathrm{C}$ for $x=0$ to $1275^{\circ} \mathrm{C}$ for $x=0.4$, indicating an effective improvement in the sinterability of $\mathrm{Ca}_{2} \mathrm{Nb}_{2} \mathrm{O}_{7}$ ceramics. The increasing density is due to the heavier mass of $\mathrm{Ba}$ atom $(137.33 \mathrm{~g} / \mathrm{mol})$ than that of $\mathrm{Ca}$ atom $(40.08 \mathrm{~g} / \mathrm{mol}) . \mathrm{In}$ addition, the relative densities of all the sintered samples were higher than $95 \%$ of the theoretical densities. Scanning electron microscope (SEM) images of the as-prepared ceramics $(x=0.1,0.2,0.3$, and 0.4$)$ are shown in Fig. 5. These ceramics have a close microstructure with low porosity. And the grains are homogeneously distributed with average grain size in the range of $2-15 \mu \mathrm{m}$, suggesting that they are suitable for subsequent characterization. 

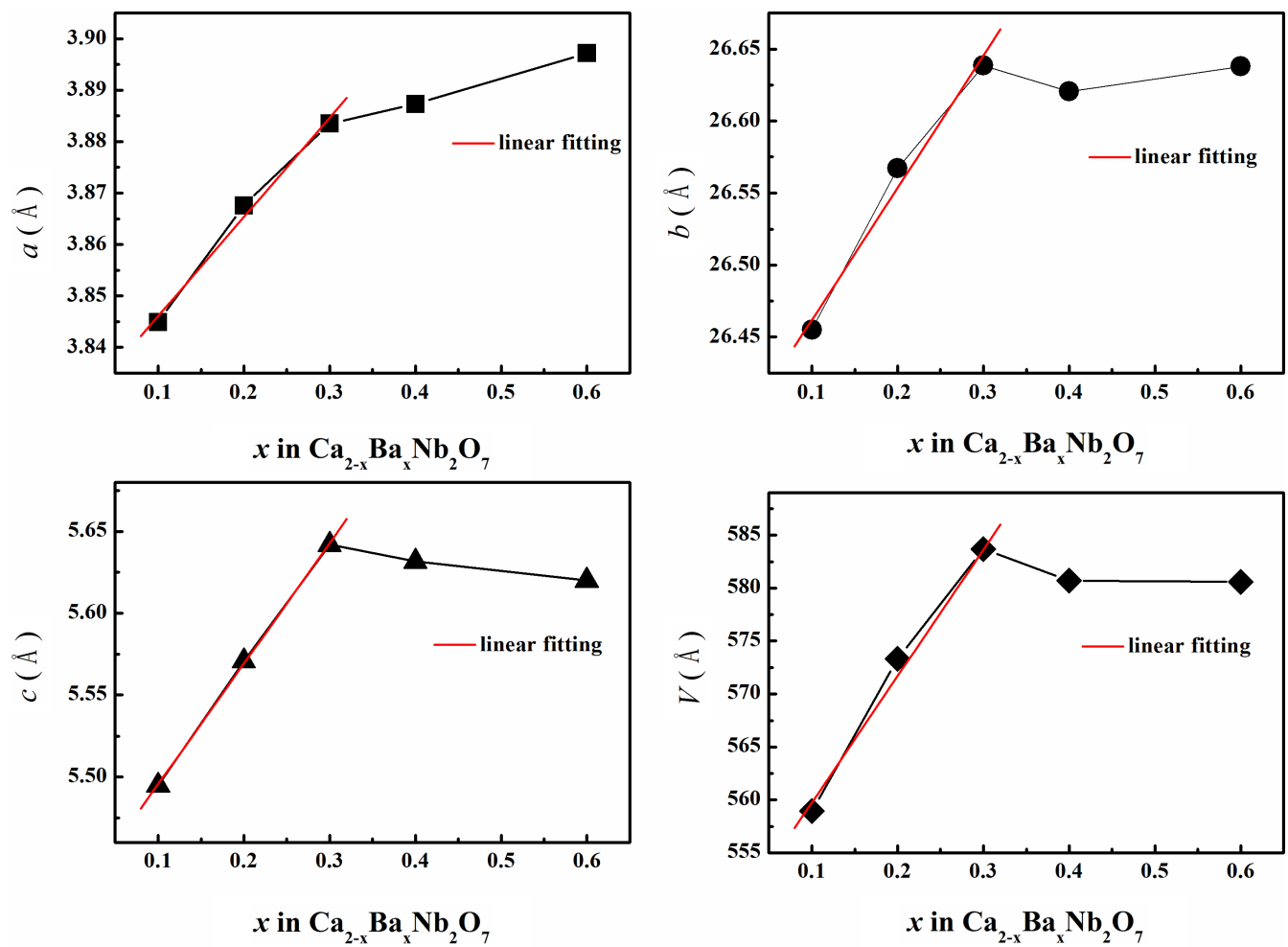

Fig. 2. Unit cell parameters $(a, b, c, V)$ of $\mathrm{Ca}_{2-x} \mathrm{Ba}_{x} \mathrm{Nb}_{2} \mathrm{O}_{7}$ (the linear fitting based on Vegard's law).

The room temperature dielectric properties are listed in Table 1 . With increasing barium doping amount, the room temperature dielectric constant is found to increase from 33.5 for $\mathrm{CBN}$ to 38.6 for $\mathrm{CBN}-0.4$, whereas the loss tangent drops almost an order of magnitude.

Figure 6 shows the temperature dependent dielectric properties measured at four fixed frequencies $(100 \mathrm{kHz}$, $500 \mathrm{kHz}$, and $1 \mathrm{MHz}$ ) for the $x=0.1$ sample. As seen, sharp

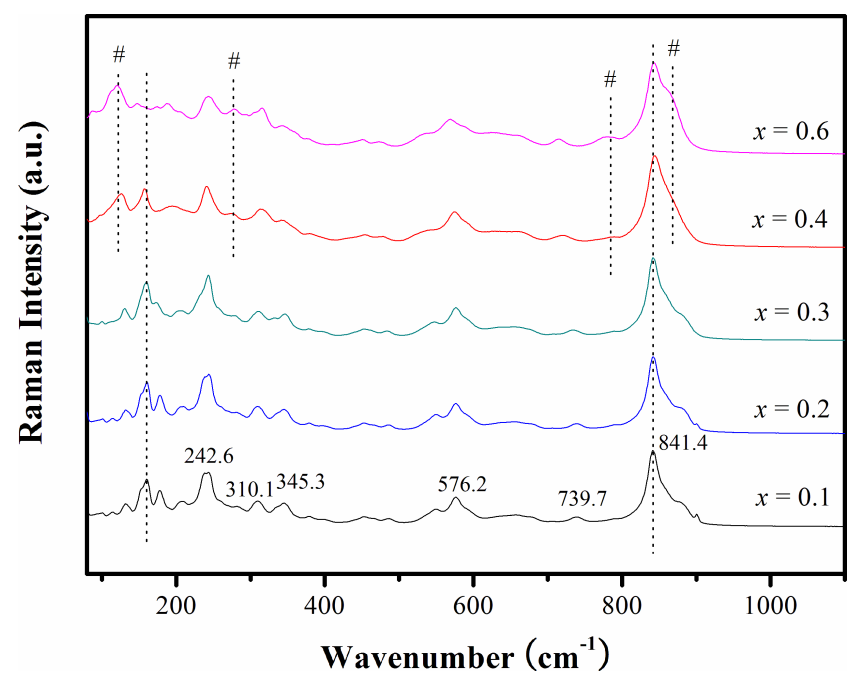

Fig. 3. The room temperature Raman spectra of $\mathrm{Ca}_{2-x} \mathrm{Ba}_{x} \mathrm{Nb}_{2} \mathrm{O}_{7}$ samples. dielectric constant peaks together with loss peaks on the $\tan \delta-T$ curves were observed for all frequencies. The characteristic temperature corresponding to the dielectric constant peaks was the Curie temperature $\left(T_{c}\right)$ for the $x=0.1$ sample with a value of $1280 \pm 5{ }^{\circ} \mathrm{C}$. Compared with the pure $\mathrm{Ca}_{2} \mathrm{Nb}_{2} \mathrm{O}_{7}$, the barium doping in CBN materials markedly decreases the Curie temperature. Similar behaviors have been reported for the barium-doped $\mathrm{Sr}_{2} \mathrm{Nb}_{2} \mathrm{O}_{7}$. It should be noted

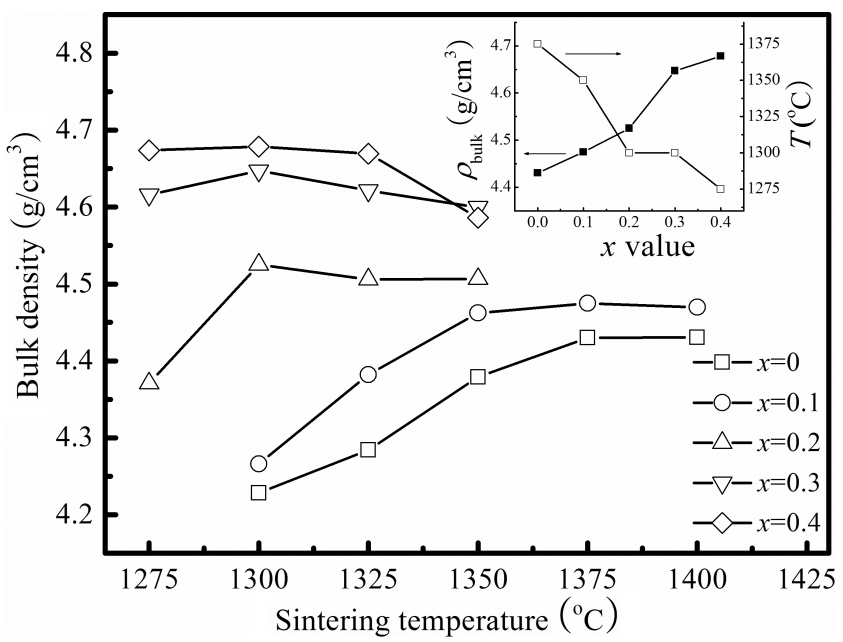

Fig. 4. Variation in bulk densities of $\mathrm{Ca}_{2-x} \mathrm{Ba}_{x} \mathrm{Nb}_{2} \mathrm{O}_{7}$ ceramics as a function of sintering temperature. 

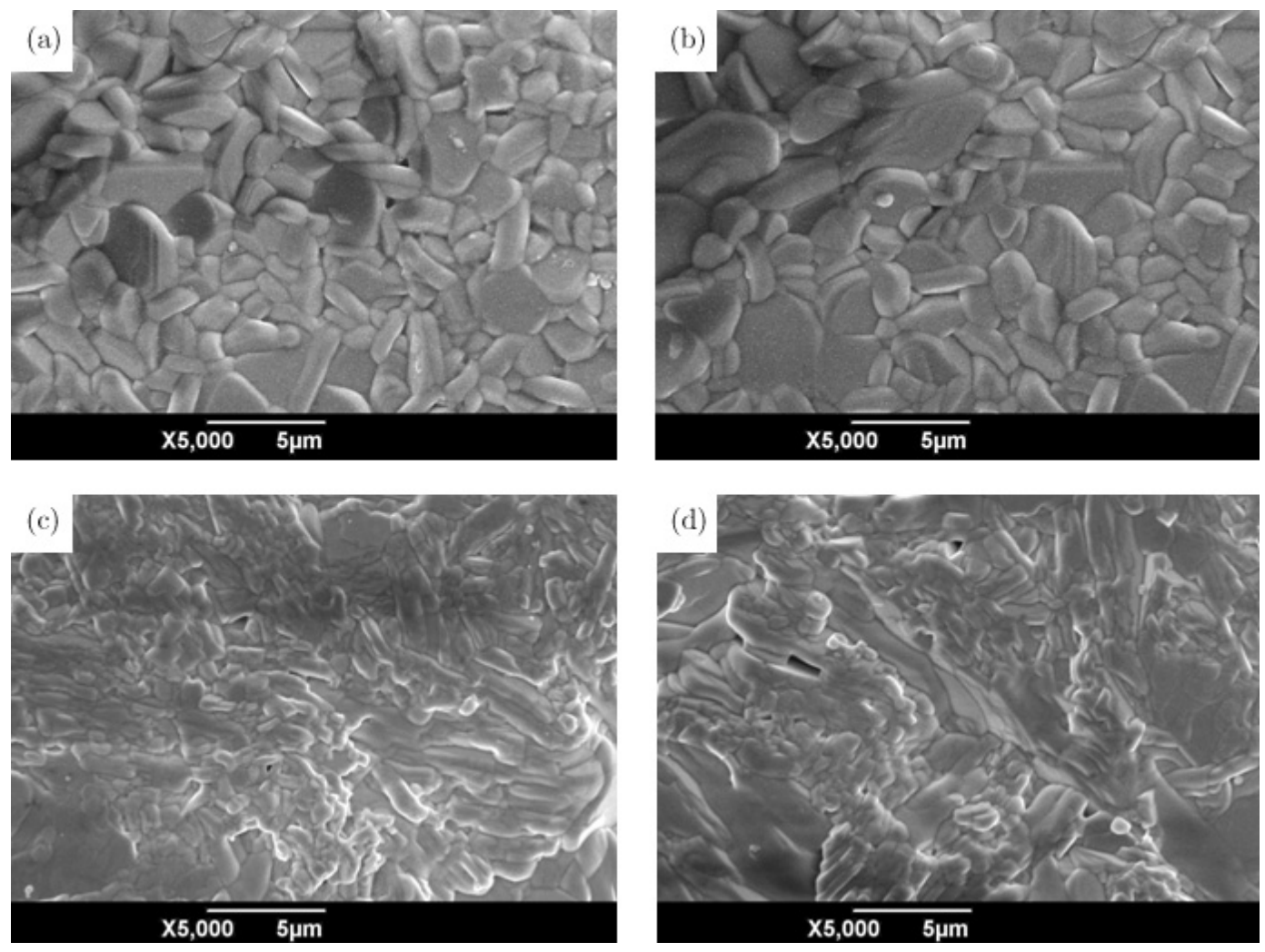

Fig. 5. Backscattered electron image of as-fired surface of $\mathrm{Ca}_{2-x} \mathrm{Ba}_{x} \mathrm{Nb}_{2} \mathrm{O}_{7}$ ceramics sintered at $1350^{\circ} \mathrm{C}:$ (a) $x=0.1$, (b) $x=0.2$, (c) $x=0.3$, and (d) $x=0.4$.

Table 1. Sintering temperature, densities and the room temperature dielectric properties of $\mathrm{Ca}_{2-x} \mathrm{Ba}_{x} \mathrm{Nb}_{2} \mathrm{O}_{7}$ ceramics.

\begin{tabular}{lcccccc}
\hline$x$ & Sintering temperature $\left({ }^{\circ} \mathrm{C}\right)$ & $\rho_{\text {th }}\left(\mathrm{g} / \mathrm{cm}^{3}\right)$ & $\rho_{d}\left(\mathrm{~g} / \mathrm{cm}^{3}\right)$ & $\rho_{r d}(\%)$ & $\varepsilon_{r}(1 \mathrm{MHz})$ & $\tan \delta(1 \mathrm{MHz})$ \\
\hline 0 & 1375 & 4.52 & 4.42 & 97.8 & 33.5 & $1.1 \times 10^{-3}$ \\
0.1 & 1350 & 4.61 & 4.48 & 97.2 & 34.4 & $8.6 \times 10^{-4}$ \\
0.2 & 1300 & 4.65 & 4.53 & 97.5 & 35.2 & $5.6 \times 10^{-4}$ \\
0.3 & 1300 & 4.71 & 4.65 & 98.6 & 36.9 & $4.2 \times 10^{-4}$ \\
0.4 & 1275 & 4.78 & 4.69 & 98.0 & 38.3 & $2.8 \times 10^{-3}$ \\
\hline
\end{tabular}

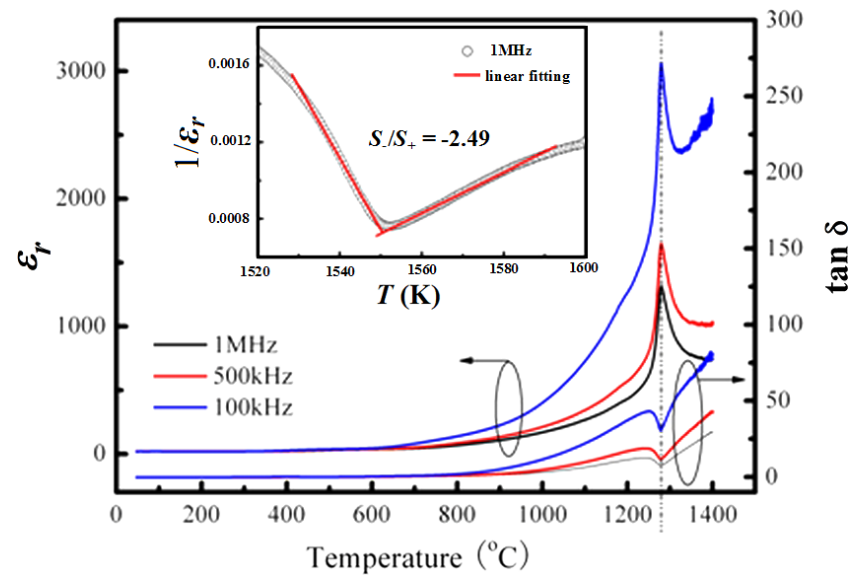

Fig. 6. The temperature dependent dielectric properties measured at four fixed frequencies $(10 \mathrm{kHz}, 100 \mathrm{kHz}, 500 \mathrm{kHz}$, and $1 \mathrm{MHz})$ for the $x=0.1$ sample. that for the other samples with $x>0.1$, it is impossible to get the $T_{c}$ values directly from the temperature dependence of dielectric properties because the ceramics began to melt at the temperature prior to the $T_{c}$ values. This also corresponds well with the lower sintering temperatures in the barium-doped $\mathrm{Ca}_{2} \mathrm{Nb}_{2} \mathrm{O}_{7}$.

From Fig. 6, it is observed that no frequency shift on the $T_{c}$ value was detected, suggesting no relaxation phenomenon in the $\mathrm{Ca}_{2-x} \mathrm{Ba}_{x} \mathrm{Nb}_{2} \mathrm{O}_{7}$ ceramics. In order to clarify the phase transition order of $\mathrm{Ca}_{2-x} \mathrm{Ba}_{x} \mathrm{Nb}_{2} \mathrm{O}_{7}$ ceramics, the heating and cooling $\varepsilon_{r}-T$ curves at $1 \mathrm{MHz}$ of the $\mathrm{CBN}-0.1$ are shown in Fig. 7. Obviously, the heating and cooling curves yield almost the same $T_{c}$ values, suggesting no thermal hysteresis. This is a common feature for the second-order phase transition. Moreover, Draegert and Singh ${ }^{18}$ proposed that the ferroelectric phase transition can be evaluated by the slopes of 


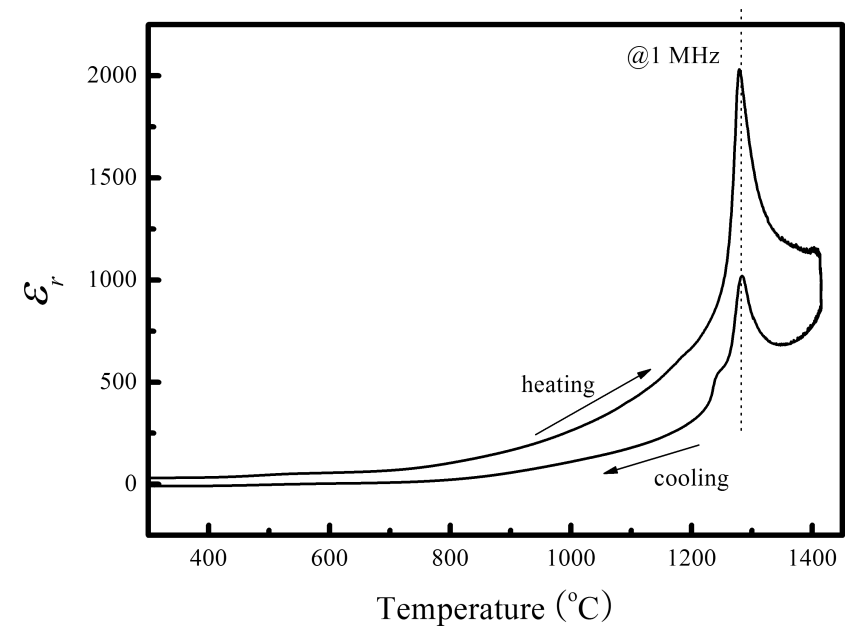

Fig. 7. The heating and cooling $\varepsilon_{r}-T$ curves at $1 \mathrm{MHz}$ of the CBN-0.1 ceramic.

the reciprocal dielectric constant versus temperature below and above $T c$ (denotes as $S-$ and $S+$, respectively). Simply, the ratio $S-/ S+$ is in the range $(-4,-2)$ the phase transition is identified as a second order type, whereas for a first order transition, the ratio $S-/ S+$ is $<-4$. As shown in the inset of Fig. 7, the ratio $S-/ S+$ in the present ceramic was -2.49 , which is close to -2 . Thus, coupling with the Fig. 7, it is reasonable to deduce a second-order transition for the $\mathrm{Ca}_{2-x} \mathrm{Ba}_{x} \mathrm{Nb}_{2} \mathrm{O}_{7}$ ceramics.

\section{Conclusions}

Investigations on the dielectric properties of the bariumdoped $\mathrm{Ca}_{2} \mathrm{Nb}_{2} \mathrm{O}_{7}$ ceramics were carried out. The solubility of $\mathrm{Ba}^{2+}$ into $\mathrm{Ca}^{2+}$ lattice was found to be limited to $\sim 30 \mathrm{~mol} \%$ on the basis of XRD and Raman results. It is also found that the barium doping slightly increased the dielectric constant of $\mathrm{Ca}_{2} \mathrm{Nb}_{2} \mathrm{O}_{7}$ and decreased the Curie temperature $\left(T_{c}\right)$ obviously. The phase transition was confirmed to be of second order based on the slopes of the reciprocal dielectric constant versus temperature below and above $T_{c}$.

\section{Acknowledgments}

This research was supported by Natural Science Foundation of China (Nos. 21561008 and 51502047), the Natural Science Foundation of Guangxi Zhuang Autonomous Region (Nos. 2015GXNSFBA139234 and 2015GXNSFFA139003, 2016GXNSFBA380134, and 2016GXNSFAA380018), Project of Scientific Research and Technical Exploitation Program of Guilin (2016010702-2), and the talent cultivation project for innovation and entrepreneurship of Beibu Gulf of Guangxi Zhuang Autonomous Region (2015-09).

\section{References}

${ }^{1}$ H. X. Yan, H. P. Ning, Y. M. Kan, P. L. Wang and M. J. Reece, Piezoelectric ceramics with super-high curie points, J. Am. Ceram. Soc. 92, 2270 (2009).

${ }^{2}$ H. Ning, H. X. Yan and M. J. Reece, Piezoelectric strontium niobate and calcium niobate ceramics with super-high curie points, J. Am. Ceram. Soc. 93, 1409 (2010).

${ }^{3}$ J. K. Yamamoto and A. S. Bhalla, Piezoelectric properties of layered perovskite $\mathrm{A}_{2} \mathrm{Ti}_{2} \mathrm{O}_{7}(\mathrm{~A}=\mathrm{La}$ and $\mathrm{Nd})$ single-crystal fibers, J. Appl. Phys. 70, 4469 (1991).

${ }^{4}$ S. Nanamatsu, M, Kimura and T. Kawamu, Crystallographic and dielectric properties of ferroelectric $\mathrm{A}_{2} \mathrm{~B}_{2} \mathrm{O}_{7}(\mathrm{~A}=\mathrm{Sr}, \mathrm{B}=\mathrm{Ta}, \mathrm{Nb})$ crystals and their solid solutions, J. Phys. Soc. Jpn. 38, 817 (1975). ${ }^{5}$ F. Lichtenberg, A. Herrnberger and K. Wiedenmann, Synthesis, structural, magnetic and transport properties of layered perovskite-related titanates, niobates and tantalates of the type $\mathrm{A}_{n} \mathrm{~B}_{n} \mathrm{O}_{3 n+2}, \mathrm{~A}^{\prime} \mathrm{A}_{k-1} \mathrm{~B}_{k} \mathrm{O}_{3 k+1}$ and $\mathrm{A}_{m} \mathrm{~B}_{m-1} \mathrm{O}_{3 m}$, Prog. Solid State Chem. 36, 253 (2008).

${ }^{6}$ F. Lichtenberg, A. Herrnberger, K. Wiedenmann and J. Mannhart, Synthesis of perovskite-related layered $\mathrm{A}_{n} \mathrm{~B}_{n} \mathrm{O}_{3 n+2}=\mathrm{ABO}_{X}$ type niobates and titanates and study of their structural, electric and magnetic properties, Prog. Solid State Chem. 29, 1 (2001).

${ }^{7} \mathrm{~S}$. Nanamatsu and M. Kimura, Ferroelectric properties of $\mathrm{Ca}_{2} \mathrm{Nb}_{2} \mathrm{O}_{7}$ single crystal, J. Phys. Soc. Jpn. 361495 (1974).

${ }^{8}$ L. Sun, J. F. Hu, F. Gao, X. W. Kong, H. W. Qin and M. H. Jiang, Room-temperature ferromagnetism and ferroelectricity of nanocrystalline $\mathrm{La}_{2} \mathrm{Ti}_{2} \mathrm{O}_{7}$, J. Alloys Compd. 502, 176 (2010).

${ }^{9}$ R. J. Cava, J. J. Krajewski and R. S. Roth, Low temperature coefficient bulk dielectrics in the $\mathrm{Ca}_{2} \mathrm{Nb}_{2} \mathrm{O}_{7}-\mathrm{Ca}_{2} \mathrm{Ta}_{2} \mathrm{O}_{7}$ system, Mater. Res. Bull. 33, 527 (1998).

${ }^{10}$ J. C. Merry, A. C. Leach and R. Ubic, Lead doped calcium niobate-tantalate pyrochlores: Phase structure and dielectric properties, Br. Ceram. Trans. 101, 143 (2002).

${ }^{11}$ H. W. Schmalle, T. Williams, A. Reller, A. Linden and J. G. Bednorz, The twin structure of $\mathrm{La}_{2} \mathrm{Ti}_{2} \mathrm{O}_{7}$ : X-ray and transmission electron microscopy studies, Acta Crystallogr., Sect. B: Struct. Sci. 49, 235 (1993).

${ }^{12} \mathrm{~K}$. Scheunemann and H. Müller-Buschbaum, Zur kristallstruktur von $\mathrm{Nd}_{2} \mathrm{Ti}_{2} \mathrm{O}_{7}$, J. Inorg. Nucl. Chem. 37, 2261 (1975).

${ }^{13}$ N. Ishizawa, F. Marumo, T. Kawamura and M. Kimura, The crystal structure of $\mathrm{Sr}_{2} \mathrm{Nb}_{2} \mathrm{O}_{7}$, a compound with perovskite-type slabs, Acta Crystallogr., Sect. B: Struct. Sci. 31, 1912 (1975).

${ }^{14} \mathrm{P}$. A. Fuierer and R. E. Newnham, $\mathrm{La}_{2} \mathrm{Ti}_{2} \mathrm{O}_{7}$ ceramics, J. Am. Ceram. Soc. 74, 2876 (1991).

${ }^{15}$ Z. P. Gao, H. X. Yan, H. P. Ning, R. Wilson, X. Y. Wei, B. Shi, H. Ye and M. J. Reece, Piezoelectric and dielectric properties of Ce substituted $\mathrm{La}_{2} \mathrm{Ti}_{2} \mathrm{O}_{7}$ ceramics, J. Eur. Ceram. Soc. 33, 1001 (2013).

${ }^{16}$ C. C. Li, H. C. Xiang, J. W. Chen and L. Fang, Phase transition, dielectric relaxation and piezoelectric properties of bismuth doped $\mathrm{La}_{2} \mathrm{Ti}_{2} \mathrm{O}_{7}$ ceramics, Ceram. Int. 42, 11453 (2016).

${ }^{17}$ J. Zhou, G. L. Feng, L. Li, F. X. Huang, H. Z. Shen, H. Yang, W. Q. Wang, Q. Zhou and D. P. Xu, In situ Raman spectroscopy and X-ray diffraction of pressure-induced phase transition in columbite $\mathrm{CaNb}_{2} \mathrm{O}_{6}$, J. Alloys Compd. 579, 267 (2013).

${ }^{18}$ D. A. Draegert and S. Singh, Dielectric susceptibility and the order of ferroelectric phase transitions, solid state communications, Solid State Commun. 9, 595 (1971). 